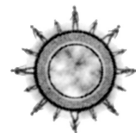

\title{
The Fictions of Autonomous Invention: Accumulation by Dispossession, Commodification and Life Patents in Canada
}

\section{Scott Prudham}

Department of Geography, Program in Planning, and the Centre for Environment, University of Toronto, Toronto, ON, Canada; scott.prudham@utoronto.ca

In 2002 the Canadian Supreme Court ruled to deny Harvard College a whole organism patent over the oncomouse. In 2004, the same court ruled that Canadian farmer Percy Schmeiser had violated Monsanto patents covering GM canola. Both decisions rejected whole organism

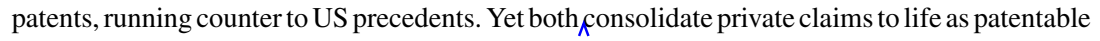
inventions, and critics claim, with some support from Justices in the Schmeiser case, that patents over genes amount to de facto patents over whole organisms. In this paper I argue these cases are broadly consistent with the notion of accumulation by dispossession as a means to expand the scale and scope of capital accumulation via so-called 'extra-economic' means. As such, I examine the cases as privatizations, but also as relational moments in the commodification of nature. However, in hoping to unpack and fill out this notion of the extra-economic, as well as to critically examine the necessarily incomplete character of commodification as a tendency, I look to the ways in which judges and interested activists deliberate over the economic, legal, ecological, ethical, and even metaphysical arguments and representations required to uphold discrete genes, processes, and whole organisms as inventions.

\section{Introduction}

On 5 December 2002, the Supreme Court of Canada ruled by a 5-4 decision to deny Harvard College a patent over its oncomouse, a rodent used in medical research and genetically engineered to contract cancer. The majority opinion argued that the mouse, as a higher life form, does not qualify as a "manufacture" or as a "composition of matter" under the Canadian Patent Act. In what seemed something of a reversal, however, only 17 months later on 21 May 2004 the same court ruled (again in a 5-4 decision) that Saskatchewan farmer Percy Schmeiser had violated a Monsanto Corporation patent over so-called "Roundup Ready" canola. In the latter ruling, the Court controversially refuted Schmeiser's right as a farmer to save seed derived from pollen drift, even if it came from Monsanto plants.

The decisions left Canada with a pair of landmark decisions that are, at least superficially, difficult to reconcile with one another. Moreover,

(C) 2007 The Autho

Journal compilation (C) 2007 Editorial Board of Antipode. 
the Harvard case leaves Canada directly at odds with the United States over intellectual property rights vis-à-vis genetically modified organisms (GMOs), conflicting as it does with a US patent issued in 1987 covering the same mouse. While Canada has generally been in league with the US in aggressively pursuing the commercialization of biotechnology, and in tandem, the restructuring of intellectual property rights to over genes and GMOs, the two SCC cases point to very real and potentially significant divergences over so-called genetic enclosures (Bridge, McManus and Marsden 2003) in the very heartland of biotech. This alone makes the cases noteworthy.

In this paper, I wish to read and interpret these cases as singular moments in the ongoing struggle to define property rights over the products of the so-called new biotechnologies, including ways in which exclusive patent and property rights act as instruments for the privatization of individual genes, biological processes, and indeed, whole organisms. I am certainly not the first to link the new biotechnologies to issues of the privatization and commodification of life (Busch 1991; Buttel 1989, 2003; Kenney 1986; Kloppenburg 2004; Thackray 1998). More generally, considerable recent literature has explored the distinct ways in which biophysical nature is commodified, a distinctness arising not least from the materiality of biophysical processes (eg Bakker 2003; Bridge 2000; Cronon 1991; Mansfield 2003; Prudham 2005). Drawing on and seeking to contribute to this literature, my goal in the paper is to use the cases (and particularly arguments mobilized by judges as well as by social and environmental activist groups) in order to better understand in particular: (i) how capital is made to circulate through biophysical nature; (ii) how this turns on the creation of new property rights and relations through so-called "extra-economic" means; and (iii) what are the politics (and political ambiguities) of resisting these various commodifications of nature?

The paper proceeds as follows. I first sketch in slightly more detail some of the basic essentials of the two cases. Subsequently, I elaborate conceptually on a set of themes related to the questions above in order to establish a more rigorous basis for examining the cases. Following this, I trace some of the historical lineage of the cases in question, linking them to the development of the new biotechnologies as key (neoliberal) strategies for expanding the scale and scope of capital accumulation. Subsequently, I visit in some detail specific arguments made for and against the extension of patent rights over full organisms in both cases. In a strictly formal sense, tensions between the cases are reconciled by the consistency with which the SCC limited life patents to discrete genes and processes and refused to extend them over whole organisms (a point of enduring disagreement on the court, but not between the two majority opinions). However, this consistency is sustained only at the costs of constructing parts of organisms as completely separable from 
their wholes, and their wholes as solely the sum of their parts. More fundamentally, it requires accepting that discrete bits of socionature can be viewed as "autonomous inventions", the products of single authors separate from prior social and biophysical contributions. This in turn, I argue, begs questions not only about the commodification of nature, but about the foundations of private property. I conclude with some reflections on some of the more explicitly normative questions and challenges posed by these cases.

\section{The Cases in Brief}

The formal history of the SCC oncomouse decision began on 21 June 1985 when the President and Fellows of Harvard College applied for a Canadian patent over "transgenic animals" genetically engineered to be susceptible to cancer. Harvard applied for a patent to cover the process of inserting the cancer causing genes into the mice, but also to cover the resulting whole mouse and, for that matter, any non-human mammal genetically engineered to develop cancer. The whole organism or product claims were rejected in 1993 by the Canadian Patent Office because the Examiner determined that whole organisms were outside the scope of the definition of "invention" in section 2 of the Canadian Patent Act. The Examiner did, however, grant the process claims (to the genes and their method of insertion). This decision was eventually overturned by the Federal Court of Appeals which granted the product patent. The Canadian government appealed, and the case went to the SCC.

Among the interesting dimensions of this decision is that it follows on and ultimately conflicts with Harvard's US oncomouse patent (see Haraway 1997). This controversial patent was awarded by the US Patent Office in 1988 and assigned to Harvard College by the principal researchers who developed it. Harvard licensed the patent to Du Pont in order to commercialize it. Rather remarkably, in the US case, a patent covering any non-human mammal genetically engineered to develop cancer was granted (see also Kevles 1998; Rifkin 1998). However, divergence between the US and Canadian patent decisions over the oncomouse was highlighted in the Canadian Federal Court, Trial Division where a Canadian judge took issue with the majority opinion in the (in)famous Diamond v Chakrabarty decision of the US Supreme Court in 1980. Siding with the minority in Chakrabarty, the Canadian judge reasoned that because separate plant breeders' protections were legislated by the 1930 US Plant Patent Act and the 1970 US Plant Variety Protection Act, Congress must have intended to keep life forms outside the scope of the US patents. The SCC majority opinion later upheld this reasoning, noting further that the mouse, as a higher life form, does not qualify as a "manufacture" or as a "composition of matter" under the Canadian Patent Act's definition of invention. Specifically: 
The sole question in this appeal is whether the words "manufacture" and "composition of matter", within the context of the Patent Act, are sufficiently broad to include higher life forms. It is irrelevant whether this Court believes that higher life forms such as the oncomouse ought to be patentable. The words of the Patent Act "are to be read in their entire context and in their grammatical and ordinary sense harmoniously with the scheme of the Act, the object of the Act, and the intention of Parliament".

The second case involved a suit brought by Monsanto against Percy Schmeiser, a conventional (ie non-organic, non-alternative) farmer from the province of Saskatchewan. According to the Court record, by 1996, about 600 farmers in Canada had embraced the use of Monsanto's Roundup Ready canola, covering approximately 50,000 acres in total. This includes many farmers in the area of Mr Schmeiser's farm. Monsanto licensed GM canola seed to farmers at a cost of $\$ 15$ per acre, and required the farmers to enter into a Technology Use Agreement. One of the terms of this agreement was that the farmers would not save seed, despite their traditional right to and practice of doing so.

By 1996, five of Mr Schmeiser's immediate neighbours in Saskatchewan were growing Roundup Ready canola on their fields. $\mathrm{Mr}$ Schmeiser saved seed that year from his fields, as he normally does. He planted the seed in the spring of 1997. Later that same season, he sprayed a public right of way near his field with Roundup, and found to his apparent surprise that $60 \%$ of the canola plants survived. In the fall of 1997, Mr Schmeiser harvested seed from the plants in this patch, and he stored the seed over the winter, and planted it the following year despite warnings from Monsanto against growing Roundup Ready canola without a license. Under court order, samples of Schmeiser's 1998 crop were taken, and it was confirmed that 95-98\% of the canola grown in these fields was Roundup Ready. Monsanto filed suit.

In its decision against Schmeiser, the Court upheld the validity of the Monsanto patent, which Schmeiser had challenged based on his claim of the right to save seed. A trial judge first upheld the patent in Monsanto Company Inc v Schmeiser, finding the patent did not contravene the Canadian Plant Breeder's Rights Act of 1990 (an act that upheld farmers' rights to save seeds), despite the fact that the GM canola can be replicated through normal plant reproduction. Upholding this reasoning, the majority argued:

The patent is valid. The respondents did not claim protection for the genetically modified plant itself, but rather for the genes and the modified cells that make up the plant. A purposive construction of the patent claims recognizes that the invention will be practiced in plants regenerated from the patented cells, whether the plants are located inside or outside a laboratory. Whether or not patent protection for the gene and 
the cell extends to activities involving the plant is not relevant to the patent's validity. (Emphasis added)

and subsequently:

Case law shows that infringement is established where a defendant's commercial or business activity involving a thing of which a patented part is a component necessarily involves use of the patented part. Infringement in this case therefore does not require use of the gene or cell in isolation. (Percy Schmeiser and Schmeiser Enterprises v Monsanto Canada and Monsanto Inc 2004, SCC 34, Per MacLachlin C J and Major, Binnie, Deschamps and Fish J J)

Critically, the dissenting opinion cited the oncomouse decision in questioning whether patents on genes and cells, reproduced as part of whole organisms, could be protected without creating de facto property rights over whole organisms:

The heart of the issue is whether the Federal Court of Appeal's decision can stand in light of this Court's ruling that plants as higher life forms are unpatentable. A purposive construction that limits the scope of the respondents' claims to their "essential elements" leads to the conclusion that the gene claims and the plant cell claims should not be construed to grant exclusive rights over the plant and all of its offspring. (Emphasis added) (Percy Schmeiser and Schmeiser Enterprises v Monsanto Canada and Monsanto Inc 2004, SCC 34, Per Iacobucci, Bastarache, Arbour and LeBel J J)

The end result however, was that Schmeiser, by this time axcause celebre among anti-GM activists and defenders of farmers' rights to save seed around the world, was found to have violated Monsanto's patents. Monsanto's award in the case was financially insignificant, perhaps some sign of the Court's sympathy. Still, the case bolstered the company's proprietary claims over a variety of one of the more commercially successful GM crops in the world, all the more significant since it took place in Canada, the world's leading producer of GM canola (Clive 2004).

\section{Stretching and Deepening: Accumulation by Dispossession and the Commodification of Nature}

These cases together comprise two landmark Canadian Supreme Court decisions that both reflect but also shape the ways patent and other intellectual property rights delineate and designate discrete genes, biological processes and whole organisms as exclusive forms of individuated, alienable (and saleable) property. One case upholds the rights of Monsanto to claim at least discrete bits of GM canola as its exclusive property, constrains the power of farmers to save GM seed, and makes farmers responsible for the random pollen drift of corporate canola. The other 
case constrains Harvard's (and DuPont's) capacity to claim (and market) outright ownership over the oncomouse. The cases also seem in tension with one another based on the reasoning of the minority in the Schmeiser case, ie that patents to parts provide de facto patents to wholes. More definitively, the decisions contravene US precedent in granting outright patents over whole organisms even as they help to internationalize the private ownership of genes.

Before discussing the cases, their historical context, and some of the arguments mobilized in the course of the Court's deliberations, I wish to discuss in greater detail a set of overarching themes, both theoretical and political, to which I believe these cases speak, specifically in relation to debates, again both theoretical and political, about the privatization and commodification of nature, and more specifically, of life. The first of these themes is that of the relational character of privatization and commodification.

Bakker (2005) has recently warned of a need to distinguish between commercialization, privatization, and commodification. In a certain sense, I agree, it is important not to collapse discrete and potentially quite different dynamics into overly broad generalizations; the term commodification, whether mobilized analytically or polemically, carries this risk. And these cases, at least directly, concern private property claims over living organisms and parts thereof as inventions. At the same time, there is a danger of overemphasizing the distinctions between privatization and commodification. Thus, I argue it is more useful conceptually and politically to see these cases as relational moments in commodification, and specifically as instances of accumulation by dispossession (Harvey 2003). That is, rather than privatization per se, the specifics of the cases, including the technologies involved, and the lineage from which they emerge make them highly consistent in important ways with the notion of accumulation by dispossession as a means to expand the scale and scope of capital accumulation via so-called 'extra-economic' means. Viewed in this manner, attempts to privatize life forms as exclusive, alienable, and saleable property are critical junctures in the creation and augmentation of the capacity for capital, as value ${ }^{1}$ in motion, to circulate in and through biophysical nature, propelled by the value expanding tendencies of generalized and specifically capitalist commodity circulation. Privatization, and for that matter, exchange, are relational moments in specifically capitalist commodification.

I have no wish to review and debate the dynamics of capital accumulation and commodity circulation here. However, it is important to remember that capitalism is not distinguished as a form of social organization by production for exchange per se, nor are commodities unique to capitalism. Rather, what distinguishes capitalist commodification is the general and expanding character of commodity production and circulation by capitalists who deploy wage labour in doing so (Marx 1977). While 
all commodities are embodied social relations, capitalist commodities are embodied capitalist relations (albeit in myriad specific forms). This gives rise to expansionary tendencies, and uneven geographical development (Harvey 1982; Smith 1984). That said, generalized commodity production and circulation expands in two interconnected ways (i) 'stretching', ie the extension of the spatial reach of particular commodities into new or larger markets; and (ii) 'deepening', ie the appearance of more and more things as commodities, including the tendency to commodify labour power itself (Lysandrou 2005). ${ }^{2}$ These twin processes of expansion propel the tendency toward the (apparent) commodification of everything that exists, and the appearance that commodification under capitalism reaches into "every nook and cranny" (Thrift 2000). I say "apparent" because these tendencies of commodification are necessarily incomplete, not least because of the fictitiousness of money, labour and nature as key inputs whose reproduction cannot be fully incorporated into and coordinated by the circuits of accumulation and market exchange (Polanyi 1944).

In this context, accumulation by dispossession has been revised by Harvey from the classical Marxist notion of primitive accumulation in order to examine the ways in which the expansion of capital accumulation turns on the creation of new forms of private property and through which capital can then more readily circulate and be realized. This latter point is critical. As Glassman (2006) has recently discussed, accumulation by dispossession draws attention to such appropriations as ongoing features of capitalist dynamics, including in the most fully developed capitalist economies. Under accumulation by dispossession, privatization is a means by which the capacity of capital to circulate is enhanced. Privatization from this perspective is central to commodification as a dynamic expansionary process. Equally, while privatization may therefore be examined in and of itself, it may also be a relational moment in the broader processes of expanding the scale and scope of commodity circulation and capital accumulation. And given the myriad ways in which state, common, and open access property may be (and has been) turned into exclusive, private property essentially by fiat (see eg McCarthy 2004), there is no reason from a theoretical or empirical perspective to confine accumulation by dispossession in any strict or direct sense to proletarianization and the dissolution of petty commodity production in the manner in which primitive accumulation has often been interpreted (Glassman 2006). In fact, and somewhat paradoxically, individuated property rights over commodities as things helps allow for the dissolution of the very specificity of these things in the realm of exchange, which in turn allows for "capitalist commodification as a process where qualitatively distinct things are rendered equivalent and saleable through the medium of money" (Castree 2003:278). For example, if all oncomice are exclusively owned by Harvard (and licensed by DuPont) 
this is one basis by which their equivalence in exchange may be and has been determined. Thus, I argue that the specifics of these cases exemplify what Kloppenburg (2004) elegantly argued and demonstrated, namely that in the absence of state sanctioned, exclusive rights over discrete biological processes and entities, the self-reproducing character of biological organisms (typified by the seed in his analysis) poses a threat to the realization of exchange value. Without stringent protections of exclusive rights, pollen drifts, mice reproduce ${ }_{\uparrow}$ potentially undermining the realization of invested capital.

My second theme, consistent with the first, is to locate these cases at the nexus of neoliberalism and nature. Harvey (2005) (along with others) has also argued that neoliberalism may be understood (at least in substantial measure) as a broad-based and diverse set of strategies oriented to reinvigorating accumulation in the advanced capitalist nations as well as on a world scale (see also Jessop 2002; Peck and Tickell 2002). The so-called enterprising up of life $\lambda_{\text {itself (Haraway 1997) repre- }}$ sents a central and even constitutive role in this project. A proliferation of recent critical literature on neoliberalism, including its environmental dimensions, should not be confused with the history of the social processes involved, and strategies to reinvigorate the economic dynamism of leading capitalist economies in so-called knowledge sectors (including biotech) date to the early 1970s. These cases thus help exemplify the constitutive role in the emergence and consolidation of neoliberalism played by re-structuring social relations to biophysical nature (McCarthy and Prudham 2004). I attempt to fill out this argument somewhat in the next section by situating the cases in relation to an historical political economy of increasingly commercially oriented (bio)technoscience.

All this said, the cases also point to commodification as an inherently unfinished tendency. I agree with Donna Haraway that the oncomouseand GM canola for that matter-is a complex assemblage of "signs and referents all rolled into one fleshy mystery in a secularized salvation history of civilian and military wars, scientific knowledge, progress, democracy, and economic power" (Haraway 1997:85). If accumulation by dispossession highlights an extra-economic dimension to extending the scale and scope of commodity production and circulation, this only highlights the existence of irreducibly extra-economic facets of the commodification of nature (or anything for that matter) more generally. I am unsatisfied with the dichotomy between "economic" and "extraeconomic", not least because such terminology runs the risk of thinking of these as formally distinct realms. But as placeholders, they at least direct attention to the myriad ways in which what are generally received as economic processes necessarily rely upon processes not generally seen as economic. This is consistent with the argument that, where nature is concerned, "the process of commodification (or its effects) might operate rather differently depending on which particular natures are 
being commodified" (Castree 2003:275; on materiality more generally, see Bakker and Bridge 2006). And a key concern becomes attending to processes of abstraction, individuation, and alienation required to render discrete bits of biophysical nature available and equivalent for exchange in isolation from ecological context (Castree 2003). ${ }^{3}$ Robertson $(2000,2004)$ has written compellingly about the discursive production of exchange under the US EPA wetland banking program, problematizing among other things the erasure of ecological difference in exchange. Most recently, he has carefully unpacked the scientific efforts of botanists and ecologists mobilized to sustain at least an appearance of scientific rigour in rendering commensurable (and exchangeable) geographically and ecologically distinct wetlands (Robertson 2006). As he notes (2006:369), the relations between capital and science here need to be understood as "as articulations between structurally closed but operationally open (that is, autopoietic) logical $\equiv \mathrm{ms}$ " (on autopoiesis and political economy, see also Jessop 2001). $\overline{\bar{m}}$ this paper, I am keen to profile similar discursive and institutional work necessary to render the messy materiality of life legible as discrete entities, individuated and abstracted from complex social and ecological integuments. In doing so, I look to the ways in which judges and interested activists deliberate over the economic, legal, ecological, ethical, and even metaphysical arguments and representations required to uphold discrete genes, processes, and whole organisms as inventions. Much of this turns on what Haraway (1997) calls the myth of "autonomous invention", the necessary fiction that despite complex social and biophysical contributions to the (re)production of mice and canola they can be legally sustained (and exchanged) as the inventions (and thus property) of single authors (and owners). It is, on its face, rather farcical, and yet it reinforces Proudhon's telling aphorism that "all property is theft". The question in the cases is then very much which thefts receive state sanction, how and why.

The self-evident fiction of autonomous invention suggests that nature does indeed comprise a special class of commodity. For many activists (including ones who mobilized around the cases discussed here) this is the basis of an argument against the commodification of nature, an argument with which I have considerable sympathy. The naked hubris that posits genes, biological processes, and whole organisms as alienable privatized inventions is quite evidently a multi-faceted theft and ought rightly to be named as such (McAfee 2003). And one might even extend this argument beyond Kloppenburg's reasoning, to see privatization not only as a way of resolving potentially conflicting social claims to nature, but also as a legal and institutional strategy aimed at repressing the self-reproducing character of life. That is, if life forms can reproduce themselves, they make for awkward forms of intellectual property to contain, posing a constant threat of ecological transgression! There is some hint of this anxiety in the cases too. 
Yet, Proudhon's statement considered in relation to these cases points to potential limitations of this "nature as exception" argument. Perhaps nature is not as exceptional as might be supposed when considered as viable terrain for exclusive property claims. This is my fourth theme in reading the cases, and it is by no means my own idea. Put succinctly, if the supposedly ontologically stable and distinct category "nature" is better understood as a complex assemblage of semiotically and materially produced socionatures or hybrids (see eg Haraway 1991, 1997; Harvey 1996; Latour 1993; Smith 1984, 1996; Swyngedouw 1999), what implications does this have not only for the advocates of such privatizations and the fiction of autonomous invention, but also for critics? There are ambiguities here, not only in the potential reinscription of a transcendental, objective notion of nature, but also and somewhat paradoxically, in undermining the particularity of the ecological critique in the sense that complex assemblages of socio-ecological production underpin all commodities, and all inventions. The question then becomes whether to abandon the exceptionalism of the strictly ecological critique, or to expand the socionature critique to encompass all enclosures.

\section{Nature, Neoliberalism, and the Political Economy of Biotechnology}

If 1973 serves to punctuate histories of capitalist social regulation (Arrighi 1994; Harvey 1989), highlighted by fallout from the first oil shock and an emerging American fiscal crisis, it is also the year in which Stanley Cohen and Herbert Boyer "discovered" recombinant DNA. This breakthrough was foundational to the transfer of genes and gene segments between different species (splicing), and as such perhaps more than any other single discovery underpins the era of the new biotechnologies. But the so-called Cohen-Boyer process was also foundational because the successful patenting of this process by university researchers-via a claim filed in 1974 and eventually granted in 1980 (Kenney 1998) — set important precedents in the privatization of life, but also in the patenting and licensing of federally funded university research (Hughes 2001). Indeed, by 1997 when the patent expired, the CohenBoyer process had become one of the first and certainly most lucrative technologies ever to be licensed from university research, and had at the same time been focal to re-working university-industry relations in technology transfer, in biotech or otherwise.

This conjuncture, that is, a crisis of American capitalism, the emergence of a suite of new biotechnologies, and the commercialization of these technologies via restructuring of university-industry-state relations, is indeed contingent, but in no way entirely incidental. Instead, it highlights the degree to which flagging national economic competitiveness, most importantly in the US and the UK, led to the aggressive 
targeting of biotech as one of the new, so-called "information" driven sectors that would fuel economic recovery and renewal (Wright 1994). Significantly, wrangling over the Cohen-Boyer process involving two universities (Stanford and the University of California), the National Institutes of Health, and would-be commercial users was paralleled by important changes underway at Harvard, precipitated in large part by its relationship with Monsanto. In 1974, Harvard granted Monsanto the right to an exclusive worldwide license over commercial applications of research conducted at the university departing from its historic practice of opposing exclusive commercial licensing. In the following year, Harvard made a more general policy shift by ending its commitment to making health science related discoveries available free of charge. The purpose was explicitly to pursue more of the kinds of exclusive arrangements it had signed with Monsanto to capitalize on potential licensing revenues (Kevles 1998).

These precedents were central to a sea-change in university-industrystate relations in the US precipitated in large part by the commercial maturation of the new biotechnologies. They acted as templates for the Bayh-Dole Act of 1980 (PL 65-517) and its subsequent refinements, encouraging American university and government researchers to patent their federally funded discoveries while enshrining biotech as a new commercial frontier for capital accumulation (ie deepening). The result has been only too successful, particularly in the most commercially immediate of the life sciences which have been substantially subordinated to capital. For example, one estimate is that drug companies were contributing about $60 \%$ of the total costs of continuing education in the medical field in the United States by the early 1990s (Angell 2004). Moreover, there is considerable evidence of growing commercial influence on research findings (Krimsky 2003), not least via the widespread practice of ghost writing. ${ }^{4}$ Again, these tendencies are particularly evident in the lucrative medical and pharmaceutical fields.

Canada is by no means to be understood as the passive recipient of US-led technological and institutional changes in these arenas, but neither is the Canadian experience less characterized by tightly coordinated industry and state action aimed at developing a basis for national economic competitiveness through biotech. Again, I cannot do justice to this history, which to my knowledge remains to be chronicled in detail. Yet, in Canada, strategic, commercially driven research alliances between universities and private capital in the health and pharmaceuticals sectors have come to increasingly characterize the social relations of (research) production, evidenced not least at my own institution by controversy surrounding Nancy Olivieri's research partnership with Apotex, a pharmaceutical multinational. ${ }^{5}$ The commercialization of rDNA and related technologies has been focal in efforts to renew the competitiveness of Canada's national economy (Slaughter and Leslie 1997). In 
particular, amidst persistent economic stagnation in the early 1980s and under the auspices of a neoliberal federal administration, the National Biotechnology Strategy was launched with the explicit goal of providing public support for the emergence of biotech as a new avenue for private accumulation, drawing in part on the nation's existing strength in the agriculture sector (Government of Canada Industry Canada 1998). Pursuit of commercial opportunities for emerging biotechnologies remained essentially the sole focus of federal biotech policy in Canada until increasing concerns about health and environmental impacts-not least in the food sector-led to a broadening of this mandate in 1999 under the Canadian Biotechnology Advisory (Prudham and Morris fortheoming). Yet the horses were out of the barn, Canada having already emerged as one of the leading nations to embrace GM crops in commercial agriculture; by 1998, Canada ranked behind only the US and the UK in the biotech sector, and had (according to boosters within Industry Canada) "more biotechnology companies per capita than any country" (Government of Canada Industry Canada 1998). And despite the oncomouse decision, Canada has largely moved to comply with US-led efforts on the internationalization of IPRs in the biotech arena by recognizing exclusive private claims (enclosures) over genes and gene constructs and by enacting stronger patent protections for commercial plant breeders.

This context situates the SCC oncomouse and Schmeiser cases as significant but hardly isolated moments, connecting them to now relatively longstanding tendencies in the commodification of nature via commercial development of the new biotechnologies. They specifically exemplify moments in both deepening and stretching, as new forms of private property rights over life are created, and as these rights are (unevenly) internationalized. The involvement of both Monsanto and Harvard as important players in the reconfiguration of US universityindustry-state relations around commercial biotechnology as far back as the mid-1970s provides a source of continuity as well, connecting past and present. But these systemic tendencies in no way diminish the significance of political struggles over these and similar cases. Quite the opposite. Indeed, if the historical political economy of biotechnology indicates anything it is that time and again, active, extra-economic political intervention has been required to secure enclosures critical to accumulation by dispossession. Put simply, property rights do not merely evolve; they are made (Weaver 2003). Somewhat ironically and paradoxically, I found a moment when this contingency was on full display in the minority opinion in the oncomouse case, a moment where the judges were arguing for the sort of whole organism patent that Harvard had successfully obtained in the US. The judges turned to the extra-legal domain of capital investment and international economic competitiveness to argue: 
The mobility of capital and technology makes it desirable that comparable jurisdictions with comparable intellectual property legislation arrive at similar legal results. (Harvard College v Canada 2002, SCC 76, Per McLachlin C J and Major, Binnie and Arbour J J. Para B)

Though I am no lawyer or judge, I cannot imagine this recourse to mobile capital and technology is a sound basis of legal reasoning. It thereby provides a glimpse on the marshalling of broad rhetorical strategies in order to justify what is fundamentally a political intervention (whether the rights are granted or not), and thus to the open-ended character of both cases as judicial reviews of the scope of patent rights. This is also evident in the fact that, this minority opinion notwithstanding, in both decisions the SCC rejected whole organism patents of the sort endorsed in the US. How meaningful this difference is remains an open question for both speculation (see below) and subsequent observation, but it does exemplify that struggles precipitated by attempts to accumulate through dispossession can offer opportunities for openings as well as closures.

\section{Inventing "Things"}

The seemingly extra-legal reasoning evident in the minority opinion in the oncomouse case is in fact the tip of the iceberg when it comes to the collision of all manner of arguments in these cases, as the judges (and some of the interested observers) struggled to extend and limit patent rights to life. This speaks in turn to the considerable "work" required in privatizing and commodifying nature, and somewhat more abstractly, to the extra-economic ways in which discrete bits of socionature may be sustained as commodities. Some heavy discursive "lifting" (Robertson $2000,2004)$ is specifically required in pursuit of the alienation, individuation, and abstraction involved in constructing the discrete "thingness" of genes and organisms, not least in order to geographically displace them (semiotically and materially) from social and ecological context (Castree 2003). This is necessary for these discrete bits to be rendered equivalents and exchanged, but also for them to be seen as "things" invented and owned by individual inventors. Some of this work is indeed evident in the quote above, reducing what is at stake to issues of national economic competitiveness. Yet elsewhere in both decisions, both the majority and minority opinions reflect the highly complex biological, economic, political, legal, ethical and sometimes metaphysical questions surrounding exactly how a life form may be construed solely as the product and property of an autonomous inventors.

For example, in the Schmeiser case, a critical point of dissension between minority and majority opinions turned on the degree to which life forms can be considered analogous to non-biological, mechanical inventions more familiar to patent law. The issue was not only whether or not life or discrete elements of life forms (ie cells, genes, etc) can credibly 
be considered inventions, but also whether or not conferring exclusive rights to self-replicating organisms grants undue control over the whole. The majority argues that Schmeiser infringed upon Monsanto's patent in saving and using Roundup resistant seed because, although no patent claim can be recognized covering the whole organism

by analogy, then, the law holds that a defendant infringes upon a patent when the defendant manufactures, seeks to use, or uses a patented part that is contained within something that is not patented ... [T]he patented genes are not merely a "part" of the plant; rather, the patented genes are present throughout the genetically modified plant ... In that sense, the cells are somewhat analogous to Lego blocks: if an infringing use were alleged in building a structure with patented Lego blocks, it would be no bar to a finding of infringement that only the blocks were patented and not the entire structure. (Percy Schmeiser and Schmeiser Enterprises v Monsanto Canada and Monsanto Inc 2004, SCC 34, majority judgment, MacLachlin C J and Fish, para 42)

However, in the dissenting opinion authored by Justice Arbour, this analogy is rejected on the basis that life forms are distinct kinds of inventions.

there is no genuinely useful analogy between growing a plant in which every cell and every cell of its progeny are remotely traceable to the genetically modified cell and contain the chimeric gene and putting a zipper in a garment, or tires on a car or constructing with Lego blocks. The analogies are particularly weak when it is considered that the plant can subsequently grow, reproduce, and spread with no further human intervention. (Para 156)

Similarly, in the oncomouse case, the nature of life, and the manner in which elements of life forms may be individuated, abstracted, and alienated (discursively and legally) from the organisms of which they are a part became a subject of some disagreement. In the majority opinion, Justice Bastarache excludes Harvard's mouse, and higher life forms more generally, from the scope of the definition of invention as defined by any "art, process, machine, manufacture or composition of matter". He argues that this specific language, as opposed to defining what is patentable as "anything ... made by man [sic]" indicates that Parliament had in mind a restrictive definition (para 158). He then writes:

Injecting the oncogene into a fertilized egg is the but-for cause of a mouse predisposed to cancer, but the process by which a fertilized egg becomes an adult mouse is a complex process, elements of which require no human intervention. The body of a mouse is composed of various ingredients or substances, but it does not consist of ingredients or substances that have been combined or mixed together by a person. Thus, I am not satisfied that the phrase "composition of matter" 
includes a higher life form whose genetic code has been altered in this manner. (Para 162)

The minority opinion dismisses these and related arguments with piercing sarcasm and wit:

The question, then, is what, in the Commissioner's view, is the "constituent material" of the oncomouse as a physical entity? If the oncomouse is not composed of matter, what, one might ask, are such things as oncomouse "minds" composed of? The Court's mandate is to approach this issue as a matter (that slippery word in yet another context!) of law, not murine metaphysics. In the absence of any evidence or expert assistance, the Commissioner now asks the Court to take judicial notice of the oncomouse, if I may use Arthur Koestler's phrase, as a "ghost in a machine" but this pushes the scope of judicial notice too far. (Harvard College v Canada 2002, SCC 76, Binnie dissenting opinion at para 45)

This exchange is singular. Clearly, there is a debate over life itself at stake here, and in particular, whether or not life is a mere "composition of matter" consistent with the patent act's definition. The somewhat predictable argument turns on one opinion opposed to patenting whole organisms because life must be more than the sum of its parts, and in counterpoint, an opinion embracing what might be conceptualized as a sort of high modernist or unbounded embrace of reductionist science. Indeed, the minority opinion in the same exchange goes on to chastise the majority opinion as presenting a threat to "the patentability of scientific invention at the dawn of the third Millennium" (ibid).

Yet, there is something distinctly dissatisfying about the terms of the debate as constituted here, debating metaphysics at the expense of considering the extent to which the materiality of life can be exhausted by human invention. That is, if life is a mere composition of matter, it does not follow that science can fully know, bound, or contain this matter in all its complexity, much less so if the changes in question amount to the insertion of individual genes and gene constructs. Add to this that prior human transformations of this "mere composition of matter" only make the myth of the autonomous inventor even harder to sustain. In this light, it is tempting to speculate over the majority opinion's note that "Researchers who wish to use a wild mouse can catch one in the parking lot. Harvard would have no complaint" (Harvard College v Canada 2002, SCC 76, Binnie dissenting opinion at para 97). Could patents be a way not only of protecting engineered natures against illicit human reproduction, but also as a way of reining in the potentially transgressive action of biophysical processes, lest unchecked reproduction lead to the trespass of an oncomouse in the parking lot?

Exception to the fictions of autonomous invention based on its discursive erasure of prior ecological production was a key theme among 
NGOs who opposed patent rights to life forms in these cases. This is exemplified by Michelle Swanarchuk, writing on behalf of the Canadian Environmental Law Association:

An animal such as a transgenic mouse has been changed from its natural progenitors by human intervention, but the mouse into which a novel gene has been introduced, with its complexity and myriad natural qualities, is a product of nature. (Swanarchuk 2003:5, emphasis added)

One factum submitted in the Schmeiser case made similar points, but noted also how the contributions of prior social labour are ignored (dispossessed) by the heroic narrative of a single human inventor:

When Monsanto's chimeric gene is inserted into a canola plant cell, it becomes one of approximately 40,000 genes that comprise the genome of that plant. The genetically modified genes and cells at issue contribute nothing to the germination, growth, maturation, or seed production of the plant into which they may be or become incorporated ... Indeed, it is plant breeding and selection by generations of farmers which has over time contributed to the value of an agricultural plant such as canola. In North America, the genome of many other agricultural plants are also the product of decades of public investment in plant selection and breeding. (Council of Canadians, Action Group on Erosion Technology and Concentration et al 2003, para 15 and 16).

One of the striking implications of this later quote is that it points (implicitly) to something akin to socionature, that is, a transformed and produced nature, as opposed to some transcendent, external, first, or universal connotation of nature. The lineage of Monsanto's canola but also of the oncomouse helps to fill this out. Canola is in some ways the archetypal Green Revolution crop, having been intentionally refined in the early 1970s by publicly supported Canadian agricultural breeding efforts seeking to generate a variety of rapeseed whose oil is digestible for humans and livestock alike (Busch et al 1994; Tanaka et al 1999). The term "canola" is a neologism derived from "Canadian Oil Low Acid", first registered as a trademark term by the Western Canadian Oilseed Crushers' Association. The canola variety of rapeseed has proved a boon to the processed food industry as well as to the industrial livestock feed business in some measure because of its specific material properties, including in particular high oil and protein content and low acidity in the seeds, as well as extremely low levels of saturation in oils derived from crushing the seeds. Though scarcely three decades old, canola is now the world's second most significant source of vegetable oil after soy (Food and Agriculture Organization of the United Nations 2006), and it is one of the staple crops of Canada's agro-industrial complex. Canada is far and away the world leader in acreage committed to GM canola, accounting for an estimated 89\% of the world's total in 2004 (Clive 2004). 
In parallel, the oncomouse, though significantly transformed by Harvard researchers, is but one variety of the legion of lab rodents bred specifically for research. Notwithstanding references in the minority opinion to catching mice "in the parking lot", the oncomouse is better understood as a special category of companion species whose existence is inextricably linked to our own (Haraway 1997), and specifically, to biomedical efforts to better understand disease in humans via proxy research. This nature is social in part because of the degree to which breeding and production of rodents for research is a business unto itselfand in this respect, who can quibble with Justice William Binnie when he noted that "mice are already commodities" (Harvard College v Canada 2002, SCC 76, Binnie dissenting opinion at para 100)? This is in itself a highly suggestive insight, though perhaps not only in the way it was intended to be. If mice are already commodities, then what makes Harvard's changes sufficient to warrant a patent where other mice breeders have been denied such rights?

Worrying over the socionatures at stake in these cases is important, but there are ambiguities in doing so as political strategy. Recognizing and contesting the alienation of ecological production as ostensibly discrete "things" are claimed as inventions by would-be exclusive patent holders is vital. It is an important check on the ways in which the autonomous invention deepens "genetic reductionism" (McAfee 2003), robbing biophysical processes of their rightful role in the production and reproduction of canola and oncomice. It also resonates with more populist and public concerns about the commodification of life, and it is important to support these struggles (see eg Rifkin 1998). And yet, in addition to prior and ongoing biophysical contributions to reproducing canola and the oncomouse, there are also prior and ongoing social contributions, including purchased labour power. These too render problematic any claim of exclusive invention and thus ownership.

Seeing both the "matter" of non-human nature but also the socially constructed meanings ascribed to this non-human world as socionatures has become a widespread preoccupation in critical environmental scholarship (see eg Cronon 1995; Demeritt 2002; Whatmore 2002), but the issue is more than a language problem surrounding the description of discrete socionatures like canola and the oncomouse. Rather, problematizing the mythology of the autonomous inventor by recourse to socionature as opposed to an external, objective, or universal sense of non-human nature has far-reaching consequences if all inventions and commodities are in part embodiments of prior social and biophysical contributions, as they surely must be. And while considerable difference of judicial opinion is apparent in both cases, this is based on substantial agreement that the issue is whether or not life presents special problems for patent doctrine; the doctrine itself is not in question. Thus, for Justice Arbour, the crucial difference between canola and Lego is that canola is 
self-reproducing. But can this distinction truly hold if a more relational and expansive notion of socionature is embraced? Proudhon's observation of the fine line between property and theft (dispossession) remains a productive entrée.

\section{Conclusion}

By way of conclusion, I would like to reflect somewhat on the specifics of these cases, and to consider some of the more explicitly normative issues raised by them. One of the most striking aspects of the oncomouse case is the way in which commodification seems to make for strange bedfellows. Here, the vanguard of a more complete privatization of life forms is Harvard College. Certainly, Harvard's role here is emblematic of neoliberal era reconfigurations of university-industry-state relations, and of social relations to nature via the commercialization of biotechnology and associated realms of technoscience. Yet it is also a caution against overly simplistic and economistic suggestions that would flatten the ideas of commodification and accumulation by dispossession by seeing them as things that "capitalists" do. Commodification, privatization, and accumulation by dispossession are irreducibly social and political processes, contingent upon and conditioned by complex configurations of social actors, including the state. In the Harvard case, the College has on the one hand sought to develop the technology and to patent it in order to leverage funds for research, both through direct royalties to be gained from licensing, and on the other hand, by awarding commercial partnerships and inviting new ones through the promise of shares in these same royalties. If the mouse is to be used by Harvard researchers and their exclusive partners, seeking patent protection is hardly classic capital accumulation in as much as the mouse represents not only exchange but also use value to its producer. At the same time, Harvard's controversial arrangement with DuPont in providing (aka selling) the latter an exclusive right to license the oncomouse for use in research suggests that "academic capitalism" (Slaughter and Leslie 1997) is hardly a stretch (see Marshall 2002).

In the Schmeiser case, romantic depictions of Percy Schmeiser as the hero in his fight against Monsanto, particularly vis-à-vis his defense of farmers' rights to save seed, somewhat disguise the degree to which this case can also be read as a fight over the dissolution of petty commodity production. The conventional canola grown by Schmeiser before 1996 was also a commodity, and he a commodity producer, albeit in the vein characteristic of intensive, (nominally) independent family farming. The shift, then, from a more common to a more closed property regime vis-àvis canola germplasm is more of a consolidation of nature's commodification and the capacity for capital to circulate through biophysical nature in agriculture, tendencies that are longstanding and uneven (Goodman, 
Sorj and Wilkinson 1987; Kautsky 1988; Kloppenburg 2004) but by no means wholly new. In short, this is not the commodification of nature de novo.

Finally, and also somewhat in response to Castree's (2003) urge for more explicit normative argumentation regarding the commodification of nature, I would like to close with some (brief) discussion of more personal views on these specific cases. In one sense, it is easy to be critical of efforts to privatize and commodify genes and whole organisms, and I doubt very much that many of Antipode's readers will find it hard to be skeptical of the efforts at enclosure mounted here by Monsanto and Harvard. Each offers normative arguments in their defense. Monsanto, in response to critics of its global biotechnology strategy, has rolled out a slick campaign around retaining profitability and improving efficiency in the agriculture sector (and thus invoking the sacred cow of agrarian populism, the family farm), while at the same time claiming to reduce the economic and environmental costs of food production (see http://www.monsanto.com/monsanto/layout/default.asp). The claim that commercial biotechnology is actually increasing yields and reducing the costs of food has been subject to serious critique by activists and academics alike, and although there are nuances, Monsanto's claims to legitimacy fly in the face of reason given the company's role in deepening productivist agriculture, and of reinforcing the industrial appropriation of on-farm production, subordinating farmers to agro-industrial capital. Moreover, Monsanto's PR campaign flies in the face of serious scholarship, indicating time and again that food shortages are socially produced $_{\lambda}$ and that on a global basis, there is no shortage of food. In this context, I do not find it hard to oppose Monsanto's claims not only that the company has invented whole organisms, but also specific gene constructs, and I do not feel at all ambivalent in my opposition to efforts at enclosing the genetic foundations of the global food system led by agricultural and pharmaceutical companies. It strikes me that, if anything, Monsanto's own championing of the possibilities opened by genetic engineering, including a new generation of so-called "pharm" crops, reinforce what for some has been an old theme in the biotech debate: the problem is not the technologies themselves, but rather the social relations and imperatives that develop and sustain them (see eg Kloppenburg 2004)

If there is ambivalence I feel in relation to the Monsanto case, it has to do with the particularisms seemingly required to oppose the company's claims. While some opinions on the Court and among the civil society groups that mobilized around this case found comfort in differentiating between patents over genes, and patents over organisms, exclusive ownership of genes seems to me to be a thin edge to the wedge for exclusive ownership of plant and animal varieties. I find little comfort that neither Monsanto nor Harvard obtained whole organism patents in these 
cases, and indeed whether or not their product and process patents give each de facto rights over whole organisms remains a tension evident within the cases. Schmeiser's lawyers pushed this issue unsuccessfully, but a strong minority opinion held that Monsanto's product and process patents effectively conferred whole organism ownership in all but name. The issue may not be fully resolved from a legal standpoint in Canada, and time will tell if patents to parts inseparable from (or useless without) the wholes are any difference from patents to the wholes. But it bears repeating that this renders patents over specific genes no less problematic. These are discoveries, not inventions. I thus support the important work being done by environmentalists, farm groups, religious organizations, academics and others around the world who oppose the corporate biotechnology agenda of enclosing genetic diversity as private property. Nevertheless, I am ambivalent about the longer term efficacy of this exceptionalism if it requires recourse to ideas of an external and universal nature, as noted above. Opposition to life patents as domains of exception tends to leave unexamined the thorny issue of how any patent is justified given the fictions of autonomous invention. To me these cases strongly suggest that the entire exercise of awarding patents turns on hair-splitting in order to discursively and institutionally produce discrete "things", sever them from contending use values via state sanction of exclusive property rights, and thereby allow them to circulate as exchange values. These may be necessary fictions, but they are no less fictions.

In the Harvard case, it is slightly more difficult to feel clearly about what is "the right thing". I am cynical of Harvard's intentions here, driven as they are by a degree of entrepreneurialism that seems crass to say the least. Looking back to 1975 when Harvard reversed its commitment to open access provision of health-related research findings, one can argue this reversal is about securing adequate return for the university's investments in research during an era of declining and threatened public commitments to research, particularly of the basic variety (Wright 1994). In this sense, how is Harvard's insistence on profiting from its oncomouse wrong? In addition, advocates for granting the oncomouse patent argue that Canada will suffer in relation to the United States if denial of the patent means that potentially path-breaking cancer research will not be conducted in Canada because Harvard will not make the mouse available. I lost a close friend to cancer recently. It may well be that additional deaths or morbidity from cancer, a disease that increasingly touches most of our lives, will result if Harvard does indeed deny the use of the oncomouse in Canada. At the same time, there is no evidence so far that Harvard has actually withdrawn the mouse from circulation north of the border, likely because the process patents governing production of the oncomouse in Canada upheld in the case will suffice to protect their investment. And anyone who wants to defend Harvard's 
insistence on profiting from the oncomouse will have to address whether or not the University's financial or academic standing was really under threat in 1975, not to mention whether an institution with an endowment now just shy of US $\$ 26$ billion can credibly cry poor.

\section{Acknowledgements}

This research was supported by the Social Sciences and Humanities Research Council of Canada under a standard research grant as well as via a Major Collaborative Research Initiative entitled "Globalization and Autonomy". Thanks to William Coleman for conversations specifically regarding biotech and property rights, and to Morgan Robertson, Noel Castree, and Erik Swyngedouw for (hopefully ongoing) conversations about the commodification of nature. I am grateful to Emily Eaton, Paul Jackson, Mark Kear, Becky Mansfield, Melissa Wright, Kathy McAfee, Roger Picton, Neil Smith, Tom Young and two anonymous reviewers for helpful comments on an earlier draft. Any errors or ambiguities in this version are my exclusive responsibility.

\section{Endnotes}

${ }^{1}$ I remain agnostic about the ontological character of value, and in particular, about the labour theory of value. For my purposes here, I would argue this is not crucial. What is crucial is Marx's view that the competitive dynamics of capital accumulation are inherently expansionary and propel a constant search for new avenues of circulation and realization. For concise elaboration, see Harvey (1982).

${ }^{2}$ Lysandrou actually places considerable emphasis on deepening as the tendency toward commodification of labour power. However, as he also notes (and drawing on Marx), dispossession of the means for reproducing labour power, requisite for the commodification of labour power, turns in large part on the provision of the means of social reproduction as commodities.

${ }^{3}$ I take these terms from Castree's (2003) discussion of some of the different facets of the commodification of nature. He also argues that privatization, displacement and valuation are required. Obviously, privatization is a key concern in the paper. I leave the questions of displacement and valuation largely unexplored.

${ }^{4}$ Ghost writing involves staff with private firms writing up all or significant portions of journal articles and publishing them under the authorship of academics. The practice is widespread in medicine.

${ }^{5}$ Olivieri discovered health risks associated with a drug called deferiprone in the course of conducting her industry-sponsored clinical trials of the drug involving patients suffering from thalassemia, a serious blood disease. Apotex, the manufacturer of the drug and sponsor of the trials, threatened legal action against Olivieri should she disclose the information. She published her findings in 1998 and was then subjected to a public campaign aimed at discrediting her. The University of Toronto rather belatedly came to her defense after being pressed by the University of Toronto Faculty Association and the Canadian Association of University Teachers. See Thompson, Baird and Downie (2005). 


\section{References}

Angell M (2004) The Truth about Drug Companies: How They Deceive Us and What to Do About It. New York: Random House

Arrighi G (1994) The Long Twentieth Century: Money, Power, and the Origins of Our Times. London and New York: Verso

Bakker K (2003). An Uncooperative Commodity: Privatizing Water in England and Wales. Oxford and New York: Oxford University Press

Bakker K (2005) Neoliberalizing nature? Market environmentalism in water supply in England and Wales. Annals of the Association of American Geographers 95(3):542565

Bakker K and Bridge G (2006) Material worlds? Resource geographies and the "matter of nature". Progress in Human Geography 30(1):5-27

Bridge G (2000) The social regulation of resource access and environmental impact: Nature and contradiction in the US copper industry. Geoforum 31(2):237-256

Bridge G, McManus P and Marsden T (2003) The next new thing? Biotechnology and its discontents. Geoforum 34(2):165-174

Busch L (1991) Plants, Power, and Profit: Social, Economic, and Ethical Consequences of the New Biotechnologies. Cambridge, MA: Blackwell

Busch L, Gunter V, Mentele T, Tachikawa M and Tanaka K (1994) Socializing nature: Technoscience and the transformation of rapeseed into canola. Crop Science 34(3):607-614

Buttel F (1989) How epoch-making are high technologies? The case of biotechnology. Sociological Forum 4(2):247-261

Buttel F (2003) The global politics of geos: The Achilles' heel of the globalization regime? In Schurman R and Kelso D D T (eds) Engineering Trouble: Biotechnology and its Discontents (pp 152-173). Berkeley, CA: University of California Press

Castree N (2003) Commodifying what nature? Progress in Human Geography 27(3):273-297

Clive J (2004) Global status of commercialized transgenic crops: 2003. http://www.agbiotechnet.com/ Accessed 18 February 2005

Council of Canadians, Action Group on Erosion Technology and Concentration, Sierra Club of Canada, National Farmers Union, Research Foundation for Science Technology and Ecology and I. C. f. T. Assessment (2003) Factum of the intervenors. Percy Schmeiser and Schmeiser Enterprises Ltd v Monsanto Canada Inc and Monsanto Company. Supreme Court of Canada, Court File Number 29437

Cronon W (1991) Nature's Metropolis: Chicago and the Great West. New York: W W Norton

Cronon W (1995) The trouble with wilderness or getting back to the wrong nature. In Cronon W (ed) Uncommon Ground: Toward Reinventing Nature (pp 69-90). New York: W W Norton \& Co

Demeritt D (2002) What is the "social construction of nature"? A typology and sympathetic critique. Progress in Human Geography 26(6):767-790.

Food and Agriculture Organization of the United Nations (2006) Faostat. http://faostat.fao.org/ Accessed 2 April 2006

Glassman J (2006) Primitive accumulation, accumulation by dispossession, accumulation by "extra-economic" means. Progress in Human Geography 30(5):608-625

Goodman D, Sorj B and Wilkinson J (1987) From Farming to Biotechnology: A Theory of Agro-industrial Development. Oxford and New York: Blackwell

Government of Canada Industry Canada (1998) The 1998 Canadian Biotechnology Strategy: An Ongoing Renewal Process. Ottawa: Industry Canada

Haraway D J (1991) Simians, Cyborgs and Women: The Reinvention of Nature. New York: Routledge 
Haraway D J (1997) Modest Witness@Second millennium. FemaleMan Meets Oncomouse: Feminism and Technoscience. New York: Routledge

Harvey D (1982) The Limits to Capital. Oxford: Blackwell

Harvey D (1989) The Condition of Postmodernity: An Enquiry into the Origins of Cultural Change. Oxford, UK and Cambridge, MA: Blackwell

Harvey D (1996) Justice, Nature, and the Geography of Difference. Cambridge, MA: Blackwell

Harvey D (2003) The New Imperialism. Oxford and New York: Oxford University Press Harvey D (2005) A Brief History of Neoliberalism. Oxford: Oxford University Press

Hughes S (2001) Making dollars out of DNA: The first major patent in biotechnology and the commercialization of molecular biology, 1974-1980. Isis 92(3):541-575

Jessop B (2001) Regulationist and autopoieticist reflections on Polanyi's account of market economies and the market society. New Political Economy 6(2):213-232

Jessop B (2002) Liberalism, neoliberalism, and urban governance: A state-theoretical perspective. Antipode 34(3):452-472

Kautsky K (1988) The Agrarian Question. London and Winchester, MA: Zwan Publications

Kenney M (1986) Biotechnology: The University-Industrial Complex. New Haven: Yale University Press

Kenney M (1998) Biotechnology and the creation of a new economic space. In Thackray A (ed) Private Science: Biotechnology and the Rise of the Molecular Sciences (pp 131-143). Philadelphia: University of Pennsylvania Press

Kevles D (1998) Diamond v. Chakrabarty and beyond: The political economy of patenting life. In Thackray A (ed) Private Science: Biotechnology and the Rise of the Molecular Sciences (pp 65-79). Philadelphia: University of Pennsylvania Press

Kloppenburg J R (2004) First the Seed: The Political Economy of Plant Biotechnology. 2nd ed. Madison, WI: University of Wisconsin Press

Krimsky S (2003) Science in the Private Interest. Lanham: Bowman and Littlefield

Latour B (1993) We Have Never Been Modern. Brighton: Harvester Wheatsheaf.

Lysandrou P (2005) Globalisation as commodification. Cambridge Journal of Economics 29(5):769-797

Mansfield B (2003) From catfish to organic fish: Making distinctions about nature as cultural economic practice. Geoforum 34(3):329-342

Marshall E (2002) Dupont ups ante on use of Harvard's oncomouse. Science 296(5571):1212

Marx K (1977) Capital: A Critique of Political Economy. New York: Vintage Books

McAfee K (2003) Neoliberalism on the molecular scale. Economic and genetic reductionism in biotechnology battles. Geoforum 34(2):203-219

McCarthy J (2004) Privatizing conditions of production: Trade agreements as neoliberal environmental governance. Geoforum 35(3):327-341

McCarthy J and Prudham S (2004) Neoliberal nature and the nature of neoliberalism. Geoforum 35(3):275-283

Peck J and Tickell A (2002) Neoliberalizing space. Antipode 34(3):380-404

Polanyi K (1944) The Great Transformation: The Political and Economic Origins of Our Time. Boston: Beacon Press

Prudham S and Morris A (fortheeming) Making the market "safe" for GM foods: The case of the Canadian Biotechnology Advisory Committee. Studies in Political Economy

Prudham W S (2005) Knock on Wood: Nature as Commodity in Douglas-Fir Country. New York: Routledge

Rifkin J (1998) The Biotech Century: Harnessing the Gene and Remaking the World. New York: Jeremy P Tarcher/Putnam 
Robertson M (2000) No net loss: Wetland restoration and the incomplete capitalization of nature. Antipode 32(4):463-493

Robertson M (2004) The neoliberalization of ecosystem services: Wetland mitigation banking and problems in environmental governance. Geoforum 35:361-373

Robertson M (2006) The nature that capital can see: Science, state, and market in the commodification of ecosystem services. Environment and Planning D: Society and Space 24:367-387

Slaughter S and Leslie L L (1997) Academic Capitalism: Politics, Policies, and the Entrepreneurial University. Baltimore: Johns Hopkins University Press

Smith N (1984) Uneven Development: Nature, Capital, and the Production of Space. Oxford: Basil Blackwell

Smith N (1996) The production of nature. In Robertson G, Mash M, Tickner L, Bird J, Curtis B and Putnam T (eds) Future/Natural: Nature/Science/Culture (pp 33-54). London: Routledge

Swenarchuk M (2003) The Harvard Mouse and all That: Life Patents in Canada. Toronto: Publisher Canadian Environmental Law Association Publication \#454

Swyngedouw E (1999) Modernity and hybridity: Nature, regeneracionismo, and the production of the Spanish waterscape, 1890-1930. Annals of the Association of American Geographers 89(3):443-465

Tanaka K, Juska A and Busch L (1999) Globalization of agricultural production and use: The case of the rapeseed sector. Sociologia Ruralis 39(1):54-77

Thackray A (ed) (1998) Private Science: Biotechnology and the Rise of the Molecular Sciences. Philadelphia: University of Pennsylvania Press

Thompson J, Baird P and Downie J (2005) The Olivieri case: Context and significance. Ecclectica, December

Thrift N (2000) Commodity. In Johnston R J, Gregory D, Pratt G and Watts M (eds) The Dictionary of Human Geography (pp 95-96). Malden, MA: Blackwell

Weaver J C (2003) The Great Land Rush and the Making of the Modern World, 16501900. Montreal: McGill-Queen's University Press

Whatmore S (2002) Hybrid Geographies: Natures, Cultures, Spaces. Thousand Oaks, CA: Sage

Wright S (1994) Molecular Politics: Developing American and British Regulatory Policy for Genetic Engineering, 1972-1982. Chicago: University of Chicago Press

(C) 2007 The Autho

Journal compilation (C) 2007 Editorial Board of Antipode. 


\section{Please correct and return this set}

Please use the proof correction marks shown below for all alterations and corrections. If you wish to return your proof by fax you should ensure that all amendments are written clearly in dark ink and are made well within the page margins.

\begin{tabular}{|c|c|c|}
\hline Instruction to printer & Textual mark & Marginal mark \\
\hline Leave unchanged & ... under matter to remain & ( ) \\
\hline $\begin{array}{l}\text { Insert in text the matter } \\
\text { indicated in the margin }\end{array}$ & $h$ & $\begin{array}{l}\text { New matter followed by } \\
h \text { or } h \otimes\end{array}$ \\
\hline Delete & $\begin{array}{l}\text { I through single character, rule or underline } \\
\text { or }\end{array}$ & $\sigma$ or $\sigma / \otimes$ \\
\hline $\begin{array}{l}\text { Substitute character or } \\
\text { substitute part of one or } \\
\text { more word(s) }\end{array}$ & / through letter or & $\begin{array}{l}\text { new character / or } \\
\text { new characters / }\end{array}$ \\
\hline Change to italics & — under matter to be changed & $\leftarrow$ \\
\hline Change to capitals & $\equiv$ under matter to be changed & $\equiv$ \\
\hline Change to small capitals & $=$ under matter to be changed & $=$ \\
\hline Change to bold type & $\sim$ under matter to be changed & $\sim$ \\
\hline Change to bold italic & $\approx$ under matter to be changed & $\underline{s i n}$ \\
\hline Change to lower case & Encircle matter to be changed & $\not$ \\
\hline Change italic to upright type & (As above) & \\
\hline Change bold to non-bold type & (As above) & \\
\hline Insert 'superior' character & $\begin{array}{l}\text { I through character or } \\
K \text { where required }\end{array}$ & $\begin{array}{l}y^{\prime} \text { or } y \\
\text { under character } \\
\text { e.g. } y^{2} \text { or } y^{2}\end{array}$ \\
\hline Insert 'inferior' character & (As above) & $\begin{array}{l}\text { L } \\
\text { over character } \\
\text { e.g. } \hat{\imath}\end{array}$ \\
\hline Insert full stop & (As above) & $\odot$ \\
\hline Insert comma & (As above) & , \\
\hline Insert single quotation marks & (As above) & $\begin{array}{l}\dot{y} \text { or } \dot{X} \text { and/or } \\
\dot{y} \text { or } \dot{X}\end{array}$ \\
\hline Insert double quotation marks & (As above) & $\begin{array}{l}\dddot{y} \text { or } \ddot{x} \text { and/or } \\
\ddot{y} \text { or } \ddot{x}\end{array}$ \\
\hline Insert hyphen & (As above) & $1-1$ \\
\hline Start new paragraph & $\digamma$ & 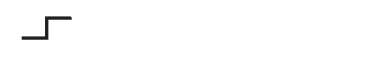 \\
\hline No new paragraph & $\infty$ & $\omega$ \\
\hline Transpose & $\sqcup$ & ᄃ \\
\hline Close up & linking $\bigcirc$ characters & \\
\hline $\begin{array}{l}\text { Insert or substitute space } \\
\text { between characters or words }\end{array}$ & $\begin{array}{l}\text { I through character or } \\
\Lambda \text { where required }\end{array}$ & \\
\hline $\begin{array}{l}\text { Reduce space between } \\
\text { characters or words }\end{array}$ & $\begin{array}{l}\text { between characters or } \\
\text { words affected }\end{array}$ & $\uparrow$ \\
\hline
\end{tabular}

